\title{
Legal Analysis of the Implementation of the Principle of Progressive Realization Obligations in Regional Financial Management In Indonesia
}

\author{
Ansar \\ Doctoral Student, Faculty Of Law, Hasanuddin University and Lecturer, Faculty Of Law, Tadulako University. \\ Indonesia
}

\begin{abstract}
The main challenge in political decentralization in Indonesia is how local government fulfil human rights by maximizing available resources. These challenges are constructed in situations where demands for the fulfilment of human rights are limited by local government budgetary conditions. While in the Human Rights Principle, Resource limitations are not a strong reason to delay the fulfilment of Human Rights, due to the obligation of progressive realization of the fulfilment of human rights. This study is entitled Legal Analysis of the Implementation of the Principle of Progressive Realization Obligations in the Management of regional finances, trying to answer several legal issues, namely; first, how is the position of the Principle of Progressive Realization Obligations in the management of regional finances; second, how to Implement Progressive Realization in the Management of regional finances; third, fulfilment of human rights in ideal regional financial management in the future. The author limits in this paper the specific ESC rights; The Right to Food, the Right to Housing and social welfare. To answer the above, the authors chose 4 regions as the object of research, namely the Bangka Belitung Archipelago Province, South Kalimantan Province, Malang City, Denpasar City and Palu City. There are a number of important things in this research that produce uncertainty in fulfilling human rights in the regions. And finally, it is necessary to improve regulations at the national and regional levels in an effort to fulfil human rights.
\end{abstract}

Keywords: Obligations of Progressive Realization, Regional Finance, Fulfilment of Human Rights.

DOI: $10.7176 / \mathrm{JLPG} / 100-06$

Publication date:August $31^{\text {st }} 2020$

\section{A. Introduction}

Irene Rubbin, a budget politician, emphasized that the public budget has no difference from other budgets. However, the public budgets have different typical, such as open-ended, involving various actors in their preparation which have different goals, use budget documents as a form of public accountability, and limitations that must be considered (budget constraints). ${ }^{1}$

The State Budget, according to Rene Stourm "The budget of the State is a document containing a preliminary approved plan of public revenues and expenditures". ${ }^{2}$ And according to Goedhart the State Budget in terms of constitutional law is the overall law that is set periodically, which authorizes the executive power to carry out expenditures for a certain period and shows the financing tools needed to cover these expenses. ${ }^{3}$ Government budgets are formed by political debate in a country and embody the values of decision makers and, ideally, the people of that country. ${ }^{4}$ While, the conception of the State Budget in the 1945 State Constitution provides a high philosophical understanding of the position of the state finances as a form of sovereignty incarnation. In other words, the nature of public revenue and expenditure in the State Budget is state sovereignty. ${ }^{5}$ To achieve that, budget policy must be based on five human rights principles: universality, justice, transparency, accountability, and participation. ${ }^{6}$

The five principles above, the basic aim is to establish clear obligations for the State, guiding the State's action towards the ultimate goal of full protection of human rights. In the Charter of ESC Rights, the States are given the freedom to gradually fulfil their rights obligations. Given the condition of the availability of resources of each participating country varies, it is possible for some participating countries that are considered to have adequate resources, it is very easy to fulfil human rights through the realization of minimum core obligations. But this is a legal problem for participating countries that have limited resources.

However, the principle stated firmly that resource limitations are not a sufficient/strong reason for the States not to carry out its obligations in the fulfilment of human rights and in terms of fulfilling human rights, it is very

\footnotetext{
${ }^{1}$ Irene S Rubin, The Politics of Public Budgeting; Getting and Spending, Borrowing and Balancing,(New Jersey: hatam, 1990)

${ }^{2}$ Rene Stourm, The Budget, (D. Appleton and Company Publisher, New York 1917), p. 4

${ }^{3} \mathrm{C}$ Goedhart, in the academic text of the draft law on State Finance (translation by Ratmoko SH. Djambatan, Jakarta 1982).

${ }^{4}$ Ann Blyberg, Human Rights Budgeting and Budget Analysis, Scottish Human Rights Commission, 2008. p. 5

${ }^{5}$ The Constitutional Court of the Republic of Indonesia, a comprehensive text on changes to the constitution of the Republic of Indonesia in 1945 Background, Process and Results Discussion in 1999-2002, REVISION EDITION, Secretariat General and Registrar of the Constitutional Court 2010. p.12

${ }^{6}$ https://www.nesri.org/programs/what-is-human-rights-budgeting Accessed on February 26th, 2019
} 
easy to prove whether a country can be said to be incapable or a state does not want/reluctant to fulfil human rights and herein lies the existence of the principle of the obligation of progressive realization.

The principle of the obligation of progressive realization is sometimes misinterpreted by saying, the obligation of progressive realization, the state can postpone the fulfilment of human rights or when the state has experienced development at a certain stage, and at the time the covenant has been realized. Regardless of the level of national wealth - to moves immediately and as early as possible to realize economic, social and cultural rights. This provision should not be interpreted as allowing the State to suspend its efforts indefinitely to guarantee the realization of the rights outlined in the Covenant. ${ }^{1}$

Many experts define the principle of the Obligation of progressive realization as a principle related to human rights under the International Covenant on ESC Rights which requires continuity, improvement in the realization of these rights by the state in real terms using available resources. ${ }^{2}$ Or the progressive realization, then, can be described as a doctrine that allows states to "partially fulfil" their human rights obligations - that is, progressively fulfilling their human rights obligations - until more resources become available. ${ }^{3}$

In connection with this goal, the doctrine of progressive realization serves as a mechanism of flexibility which takes into account the fact that most countries do not have the resources to fully protect all the rights of the Covenant, thereby giving economic, social and cultural rights to be realized gradually as more and more resources available. $^{4}$

In this paper, based on the above, formulate three problems faced in the fulfilment of human rights above, first, how is the position of the Principle of Progressive Realization Obligations in the management of regional finances, Second, Implementation of Progressive Realization in the Management of regional finances, third, fulfilment of human rights in ideal regional financial management in the future.

\section{B. The legal position of the principle of Obligations of Progressive Realization in the fulfilment of human rights in financial management}

1) The obligation to allocate a budget in the fulfilment of human rights

Five things that make the State obliged to provide resource allocation in an effort to fulfil human rights. First, under the mandate of international law enforcement and fulfilment of human rights is an obligation. Two principles of the agreement namely Pacta sun servanda and Good Faith are important principles for ensuring the fulfilment of human rights. The two principles above require the state to implement the principles of fulfilling human rights honestly and in accordance with the standards of fulfilling human rights that have been set.

The Second is the consequences of the ratification of the Economic, Social and Cultural Rights Agreement (ESC Rights). Article 2 paragraph (1):

"Each State Party to the present Covenant undertakes to take steps, individually and through international assistance and co-operation, especially economic and technical, to the maximum of its available resources, with a view to achieving progressively the full realization of the rights recognized in the present Covenant by all appropriate means, including particularly the adoption of legislative measures."

The consequences of the word "undertakes" above, based on the first reason, the Indonesian state is obliged to fully realize the rights of ECS Rights by one of them is to provide resources specifically the financial resources.

Third, the fulfilment of human rights, especially the rights of ESC Rights by the state, require huge resources, it can be said that without resources (one of them is financial), it is certain that the rights of the citizens' ESC Rights cannot be fulfilled. On this basis, if the obligation for states in fulfilling human rights, then the fulfilment process also becomes mandatory for the state. This means that the provision of a budget for fulfilling human rights above becomes mandatory.

Fourthly, several international instruments and commentaries suggest that there are obligations of a number of countries to provide a number of resources/budgets to fulfil human rights, for example:

- UN Committee on the Elimination of Discrimination against Women (CEDAW), general recommendation No. 24 (1999) concerning women and health, paragraph. 30, as follows: "States parties should allocate adequate budgetary, human and administrative resources to ensure that women's health receives a share of the overall health budget comparable with that for men's health, taking into account their different health needs."

- HRC, general comment No. 21 (1993) concerning humane treatment of persons deprived of their liberty), paragraph 4, as follows: "Treating all persons deprived of their liberty with humanity and with respect for their dignity is a fundamental and universally applicable rule. Consequently, the application of this rule, as a minimum, cannot be dependent on the material resources available in

\footnotetext{
${ }^{1}$ Committee on Economic, Social and Cultural Rights, Fact Sheet Number 16 (Revised 1), World Campaign for Human Rights

${ }^{2}$ https://referensi.elsam.or.id/2014/09/realisasi-progresif/. Accessed on May 1st, 2020

${ }^{3}$ What are Minimum Core Obligations?, Conceptualizing a Performative Standard for Economic, Social \& Cultural Rights to Complement Progressive Realization, 2018 Vol 2. p. 27.

${ }^{4}$ Ibid.
} 
the State party."

- CRC, general comment No. 2 (2002) concerning the role of independent national human rights institutions in the promotion and protection the rights of child, paragraph. 11, as follows: "While the Committee acknowledges that this is a very sensitive issue and that State parties function with varying levels of economic resources, the Committee believes that it is the duty of States to make reasonable financial provision for the operation of national human rights institutions in light of article 4 of the Convention."

Fifth, in addition to the above international legal obligations, national law also affirms the obligation to fulfil the rights of the ESC Rights with resources and budgets. For example; The 1945 Constitution of the Republic of Indonesia in Article 31 ${ }^{1}$, the 1945 Constitution of the Republic of Indonesia in Article $34^{2}$, the 1945 Constitution of Indonesia in Article $28 \mathrm{I}^{3}$ As a derivative of the 1945 Constitution, the affirmation of the fulfilment of human rights is also spread in several laws. ${ }^{4}$ For example the Human Rights Law in Article 8 as follows;

"Protection, promotion, enforcement and fulfilment of human rights are primarily the responsibility of the Government."

\section{2) Obligations of Progressive Realization in Fulfilment of Human Rights}

Limited resources in the fulfilment of human rights above, can be anticipated with Progressive Realization. As stated in article 2 paragraph (1) the International Covenant on Economic, Social and Cultural Rights stipulates that:

"Each State Party to the present Covenant undertakes to take steps, individually and through international assistance and co-operation, especially economic and technical, to the maximum of its available resources, with a view to achieving progressively the full realization of the rights recognized in the present Covenant by all appropriate means, including particularly the adoption of legislative measures."

The above article has been explained in General comment Number. 9 Characteristics of the Obligations of member states of the United Nations Committee for Economic, Social and Cultural Rights (1994):

"Obligations for the main results reflected in article 2 (1) are to take steps "with the aim of progressively achieving the full realization of the rights recognized" in the Covenant. The words "progressively achieve" are often used to explain the purpose of this phrase. The progressive realization concept demonstrates awareness of the fact that the full realization of all economic and social rights in general cannot be achieved in a short period of time. In this sense, this obligation is significantly different from what is stated in article 2 of the Covenant on Civil and Political Rights which includes an obligation to respect and guarantee the immediate implementation of the rights in the Covenant. However, the fact that a gradual manifestation, or in other words progressively, has been regulated in the Covenant cannot be interpreted as nullifying obligations in the full sense. This is on the one hand a flexible means needed, illustrating the reality of the real world and the difficulties faced by countries in ensuring the full realization of Economic, Social and Cultural Rights. On the other hand, the phrase must be understood within the scope of the overall objective, or reason, of the Covenant, namely to establish obligations for states parties with the aim of full realization of the rights contained therein. Therefore, the Covenant imposes an obligation to move as quickly and effectively as possible towards that goal. Then all retrogressive actions in this matter require careful consideration and obtain justification by reference to all rights stipulated in the Covenant and in the context that all available resources have been used." 5

The general comments mentioned above, emphasize as well as define a number of things about the obligation to gradually fulfil the rights of ESC Rights. First, that shows awareness of the fact that the full realization of all economic and social rights in general cannot be achieved in a short period of time, fulfilment can only be done gradually. Second, the position of fulfilling the rights of ESC Rights gradually cannot be interpreted as nullifying obligations in the full sense.

Third, the fulfilment of the rights of ESC Rights gradually a flexible means needed, describing the reality of the real world and the difficulties faced by countries in ensuring the full realization of economic, social and cultural

\footnotetext{
${ }^{1}$ Article 31 paragraph (2) "Every citizen is obliged to attend basic education and the state is obliged to finance it". Article 31 paragraph (4), "The State shall prioritize the education budget at least twenty percent of the state budget and from the regional budget revenue and expenditure to fulfil the needs of implementing national education."

Article 34 paragraph (3) "The State is responsible for the provision of adequate health service facilities and public service facilities".

${ }^{2}$ Article 34 paragraph (3) "The State is responsible for the provision of adequate health service facilities and public service facilities".

${ }^{3}$ Article 28 I paragraphs (4) and (5). "Protection, promotion, enforcement and fulfilment of human rights are the responsibility of the state, especially the government; and to uphold and protect human rights in accordance with the principles of a democratic rule of law, the implementation of human rights is guaranteed, regulated, and stated in statutory regulations."

${ }^{4}$ Articles 42 and 54 of Law Number 39 of 2009 concerning Human Rights, Articles 46 and 49 of Law Number 20 of 2003 concerning the National Education System, Article 18 of Law Number 18 of 2012 Concerning Food, Articles 45 and 46 of Law No. 29 of 2009 concerning Environmental Protection and Management, Article 6 of Law Number 24 of 2007 concerning Disaster Management, Article 171 of Law Number 36 of 2009 concerning Health, Article 53 and Article 71 E of Law Number 23 of 2002 concerning Protection of Child

5 in General comments Number 9 Characteristics of the Obligations of member states of the United Nations Committee for Economic, Social and Cultural Rights (1994), p. 94
} 
rights. Fourth, the Covenant obliges the state to carry out gradual fulfilment of the rights of ESC Rights to move quickly and effectively towards that goal. And fifth, it cannot be justified to carry out postponement in the fulfilment, if it occurs/is forced to postpone, the state party must explain that the state party has used its available resources optimally.

A detailed description of gradually fulfilment is also applied to various ESC rights, for example the fulfilment of free basic education rights ${ }^{1}$, the right to adequate $\operatorname{food}^{2}$, the right to adequate water ${ }^{3}$ and sanitation ${ }^{4}$, the right to work $^{5}$, the right to housing, etc.

From the above, the obligation to "achieve progressively" the full realization of the right contains two meanings, namely; First, the obligation to continuously improve conditions. The government must move as efficiently and effectively as possible towards the full realization of relevant rights. The resources allocated for the realization of the ESC Rights will increase in proportion to any increase in global resources. On the other hand, it emphasizes neither political, cultural or economic conditions cannot be accepted as a reason or justification for failing to have a full direct impact on civil and political rights. ${ }^{6}$

For the first meaning above, the principle of Immediate applies, which is an effort to provide an immediate effect on the fulfilment of the rights of ESC Rights. Under the obligation of progressive realization, the State must make continuous efforts to enhance the enjoyment of economic, social and cultural rights. This means that, although full realization can be achieved progressively, steps towards that goal must be taken in a relatively short amount of time. These steps must be deliberate, concrete and targeted as clearly as possible, using all appropriate means, including in particular but not only the adoption of legislative measures.

Second, the obligation not to take deliberate steps backward in all respects. For example, adopt a law or policy with direct negative effect or guarantee on the enjoyment of rights. Undertake an unjustified reduction in public expenditure aimed at implementing relevant rights, with no adequate compensation measures aimed at protecting the people who are harmed by this reduction. ${ }^{7}$

Progressive realization is the main key for the entire Covenant to highlight its key role in guiding state action. The idea of progressive realization represents a condition that determines the nature of state obligations by shaping how obligations are permitted to be carried out, namely the role of progressive realization to determine the nature of state actions can be described as a performance standard.

\section{Implementation of the Principle of Progressive Realization Obligations in the regions}

The obligation of progressive realization emphasizes that the obligation of the government to continuously

${ }^{1}$ General Comments Number 11 (1999) Action plan for basic education (Article 14 International Covenant on Economic, Social and Cultural Rights), paragraph 1: Article 14 International Covenant on Economic, Social and Cultural Rights requires that every State which has not secured basic education is needed, free of charge, to start, within a period of two years, the implementation of a detailed plan of action for the progressive implementation of the basic principles of education free of charge for everyone, in a realistic timeframe. Although there has been an agreement on obligations relating to article 14, some States have not drafted or implemented an action plan for basic education that is needed and is free of charge.

${ }^{2}$ General Comment Number 12, Rights to Decent Food Materials, United Nations Committee for Economic, Social and Cultural Rights E/C.12/1999/5, in paragraph 6: Right to Decent Food Materials is realized when every man, women and children, alone or in the community, have physical and economic access at all times to adequate food or ways to obtain it. Therefore, the Right to Decent Foodstuff cannot be interpreted in a narrow and limited sense that equates it with a minimum package of calories, protein and other specific nutrients. The right to adequate food must be realized progressively. However, States have a core obligation to take the actions necessary to reduce and alleviate hunger as stipulated in Paragraph 2 of Article 11, even in the event of a natural or other disaster.

${ }^{3}$ General Comment 15, Rights to Water, United Nations Committee for Economic, Social and Cultural Rights, E / C.12 / 2002/11 November 26, 2002. Paragraph 17: Although the Covenant provides a progressive realization and tolerates limitations - the limited resources available, the Covenant also imposes various obligations that must be carried out immediately. The signatory country has immediate obligations regarding the right to water, for example a guarantee that the right to water will be exercised without the slightest discrimination (article 2, paragraph 2) as well as the obligation to take steps (article 2, paragraph 1) towards full realization of article 11 paragraph 1 and article 12 . These steps must be implemented carefully, concretely and aimed at the full realization of the right to water.

${ }^{4}$ General Comment 15, Right to Water, United Nations Committee for Economic, Social and Cultural Rights, E/C.12/2002/11 November 26th, 2002. Paragraph 29: Ensuring that everyone has access to proper sanitation is not only the basis for human dignity and privacy, but also one of the main mechanisms for protecting the quality of water supplies and sources. In accordance with the right to healthy and decent housing (see General Comments number 4 (1991) and 14 (2000)) Signatories have an obligation to progressively expand safe sanitation services, especially in rural and urban poor areas, taking into account the needs of women and children.

${ }^{5}$ General Comment 18, Rights to Work, Adopted on 24 November 2005, Article 6 of the International Covenant on Economic, Social and Cultural Rights. Paragraph 19; the main obligation of the signatory state is to ensure progressive realization in the implementation of the rights to work. Therefore, the signatory country must immediately approve or implement actions aimed at achieving a non-unemployment situation. Although the covenant provides provisions for progressive realization and is aware of obstacles due to limited resources available, but the Covenant also imposes on the signatory states various obligations which must be immediately carried out.91 Signatory countries have obligations which must be carried out immediately in relation to rights for work, such as the obligation to "guarantee" that this will be carried out immediately "without discrimination in any form" (article 2 paragraph 2) as well as the obligation to "take steps" (article 2 paragraph 1) towards full realization of article 6.92 Such steps must be considered carefully, concretely and directed towards the full realization of the rights to work.

${ }^{6}$ United Nations, High Commissioner for Human Rights (OHCHR), Realizing Human Rights through Government Budgets, York and Geneva, 2017 , p. 28

${ }^{7}$ Ibid. p. 29 
improve conditions conducive to the realization of human rights means that the resources allocated for the realization of the ESC Rights must increase proportionately to the increase in overall resources. And to ensure that the government budget is used to progressively fulfil human rights, the allocation for fields related to economic and social rights must increase at least to the same level as the overall budget. In other words, if the total government budget increases 5 percent from one year to the next, funding for important fields such as education, health and water must increase by 5 percent or more. At the same time the government's obligation to avoid retrogressive actions implies that there should be no unjustified reduction in public spending aimed at implementing ESC Rights. ${ }^{1}$

\begin{tabular}{|c|c|c|c|c|c|c|c|c|c|}
\hline \multicolumn{10}{|c|}{ DEVELOPMENT OF INCREASING THE REGIONAL HOUSING BUDGET } \\
\hline \multirow[b]{2}{*}{ No. } & \multirow[b]{2}{*}{ REGION } & \multicolumn{8}{|c|}{ TOTAL BUDGET } \\
\hline & & $\begin{array}{c}\text { HOUSING } \\
\text { BUDGET IN } \\
2017\end{array}$ & $\%$ & $\begin{array}{c}\text { HOUSING } \\
\text { BUDGET IN } \\
2018\end{array}$ & $\%$ & $\begin{array}{c}\text { HOUSING } \\
\text { BUDGET IN } \\
2019\end{array}$ & $\%$ & $\begin{array}{c}\text { HOUSING } \\
\text { BUDGET IN } \\
2020\end{array}$ & $\%$ \\
\hline 1 & $\begin{array}{c}\text { BANGKA BELITUNG } \\
\text { ARCHIPELAGO PROVINCE }\end{array}$ & & & 30.005 .729 .555 & 1 & 21.864.669.094 & 1 & 29.692 .321 .356 & 1 \\
\hline 2 & $\begin{array}{l}\text { SOUTH KALIMANTAN } \\
\text { PROVINCE }\end{array}$ & & & 46.682 .355 .000 & 1 & 38.452 .482 .000 & 1 & 37.635 .680 .750 & - \\
\hline 3 & MALANG CITY & & & 95.784 .669 .100 & 5 & 98.711 .815 .740 & 4 & 40.118 .824 .343 & 1 \\
\hline 4 & PALU CITY & & & 86.625 .705 .245 & 6 & 48.620 .436 .035 & 3 & 72.905 .084 .570 & 3 \\
\hline 5 & DENPASAR CITY & 26.219 .936 .140 & 1 & 35.080 .754 .594 & 1 & 37.558 .206 .430 & 2 & & \\
\hline
\end{tabular}

\begin{tabular}{|c|c|c|c|c|c|c|c|c|c|}
\hline \multicolumn{10}{|c|}{ DEVELOPMENT OF INCREASING THE REGIONAL SOCIAL BUDGET } \\
\hline \multirow[b]{2}{*}{ No. } & \multirow[b]{2}{*}{ REGION } & \multicolumn{8}{|c|}{ TOTAL BUDGET } \\
\hline & & $\begin{array}{c}\text { SOCIAL } \\
\text { BUDGET IN } \\
2017 \\
\end{array}$ & $\%$ & $\begin{array}{c}\text { SOCIAL } \\
\text { BUDGET IN } \\
2018 \\
\end{array}$ & $\%$ & $\begin{array}{c}\text { SOCIAL } \\
\text { BUDGET IN } \\
2019 \\
\end{array}$ & $\%$ & $\begin{array}{c}\text { SOCIAL } \\
\text { BUDGET IN } \\
2020 \\
\end{array}$ & $\%$ \\
\hline 1 & $\begin{array}{c}\text { BANGKA BELITUNG } \\
\text { ARCHIPELAGO PROVINCE }\end{array}$ & & & 39.759 .862 .616 & 1 & 48.356 .492 .184 & 1 & 34.923 .767 .514 & 1 \\
\hline 2 & $\begin{array}{l}\text { SOUTH KALIMANTAN } \\
\text { PROVINCE }\end{array}$ & & & 86.816 .945 .050 & 1 & 91.394 .914 .984 & 1 & 108.317 .476 .992 & 1 \\
\hline 3 & MALANG CITY & & & 28.345 .840 .700 & 1 & 29.177 .584 .265 & 1 & 46.310 .981 .146 & 2 \\
\hline 4 & PALU CITY & & & 61.470.630.334 & 4 & 45.284.081.208 & 3 & 23.451.003.868 & 1 \\
\hline 5 & DENPASAR CITY & 7.585 .022 .500 & 0 & 9.720 .382 .401 & 0 & 10.951 .504 .971 & - & & \\
\hline
\end{tabular}

\begin{tabular}{|c|c|c|c|c|c|c|c|c|c|}
\hline \multicolumn{10}{|c|}{ DEVELOPMENT OF INCREASING THE REGIONAL FOOD BUDGET } \\
\hline \multirow[b]{2}{*}{ No. } & \multirow[b]{2}{*}{ REGION } & \multicolumn{8}{|c|}{ TOTAL BUDGET } \\
\hline & & $\begin{array}{c}\text { FOOD } \\
\text { BUDGET IN } \\
2017 \\
\end{array}$ & $\%$ & $\begin{array}{c}\text { FOOD } \\
\text { BUDGET IN } \\
2018 \\
\end{array}$ & $\%$ & $\begin{array}{c}\text { FOOD } \\
\text { BUDGET IN } \\
2019 \\
\end{array}$ & $\%$ & $\begin{array}{c}\text { FOOD } \\
\text { BUDGET IN } \\
2020 \\
\end{array}$ & $\%$ \\
\hline 1 & $\begin{array}{l}\text { BANGKA BELITUNG } \\
\text { ARCHIPELAGO PROVINCE }\end{array}$ & & & 9.871 .182 .267 & 0 & 11.886 .983 .426 & - & 11.427 .709 .885 & - \\
\hline 2 & SOUTH KALIMANTAN PROVINCE & & & 86.816 .945 .050 & 1 & 91.394 .914 .984 & 1 & 108.317.476.992 & 1 \\
\hline 3 & MALANG CITY & & & 1.391 .095 .000 & 0 & 1.092 .778 .000 & - & 14.280 .736 .249 & 1 \\
\hline 4 & PALU CITY & & & 61.470 .630 .334 & 4 & 34.776.488.074 & 2 & 27.159.386.443 & 1 \\
\hline 5 & DENPASAR CITY & 12.994 .079 .700 & 0 & 13.791.623.612 & 1 & 13.340 .403 .890 & 1 & & \\
\hline
\end{tabular}

A search of the 5 regions that were the object of the study can be concluded. In general, there was a significant increase in the budget in each region. Although the region of South Kalimantan Province ${ }^{2}$ in 2020 there was a significant decrease in the budget of around $17 \%$, but there was a significant increase in the budget in regions such as Palu City ${ }^{3}$, Malang $\mathrm{City}^{4}$, and Bangka Belitung Archipelago Province which were the object of the study.

Based on the above table, the authors draw some conclusions based on the principle of the obligation of progressive realization. First, the increase in the Regional Budget Revenue and Expenditure each year in the region does not affect the increase in the budget of fulfilling human rights in the region.

Second, progressive realization of budget requires a budget gradual increase, but if you look at the table above, in almost all regions there is no progressive increase in every year. From the tables above, especially in matters of food, housing and social, there is no annual budget development, the opposite happened for Palu and Malang city. In fact, in all of the above regions there has been budget decrease in the fields related to ESC rights.

In the above has been mentioned the progressive realization of the two fields which need to be emphasized

\footnotetext{
${ }^{1}$ United Nations High Commissioner for Human Rights (OHCHR) and International Budget Partnership, Realizing Human Rights through Government Budgets, New York and Geneva, 2017.p. 99

${ }^{2}$ See Regional Regulation Number 15 of 2017 concerning the South Kalimantan Province Regional Budget Revenue and Expenditure in 2018 Appendix V, See Regional Regulation 6 of 2018 on the South Kalimantan Provincial Budget Revenue and Expenditure in 2019 Appendix V, See Regional Regulation number 13 of 2019 concerning Regional Budget Revenue and Expenditure of South Kalimantan Province in 2020 Appendix V,

${ }^{3}$ See Regional Regulation number 15 of 2017 concerning the regional budget revenue and expenditure of Palu City in 2018 Appendix V, See Regional Regulation 6 of 2018 concerning the regional budget revenue and expenditure of Palu City in 2019 Appendix V, See Regional Regulation Number 13 of 2019 concerning the Regional Budget Revenue and Expenditure Palu City 2020 Appendix V.

${ }^{4}$ See Regional Regulation Number 7 of 2017 concerning Regional Budget Revenue and Expenditures Malang City 2018 Appendix V.
} 
in budget management, first is the continuous improvement of human rights conditions, especially in the budget development towards the fulfilment of ESC rights, and secondly it does not take a step back in the allocation/fulfilment of ESC rights.

The above regional financial management can be said to have been contrary to the principle of progressive realization, the table above shows that there was no development of the budget in the fields of education, health, housing, food, and social. What actually happened was the reduction in the budget above. And this action clearly influences the promotion and fulfilment of human rights in the regions.

\section{Policy Principle of Obligations of Progressive Realization and its Impact On The Fulfilment Of Human Rights In The Future}

Our current problem is that regional financial management has not yet given a high effect on the fulfilment of human rights. In terms of expenditure is a form of realization of regional government work plans in the implementation of services and development. The activities of the regional government will only be felt by the community when the expenditure process is completed, such as spending on providing infrastructure, spending on subsidies, spending on education, and others. Hence, one of the strategic points of government administration is state expenditure. The expenditure mechanism must be arranged so that the expenditure process can be carried out in a controlled manner. The government as a non-profit organization is indeed not required to generate profits, but that does not mean they can spend money at will.

There are three meanings of finance/expenditure that are often forgotten for the administration of state/region in the management of regional finances. First the definition of regional finance as a Democratic Governance Framework places the Regional Budget as a people's trust entrusted to the executive and legislative institutions to be managed for the people's welfare. Second, the regional budget as people's sovereignty, the use must reflect the needs of the people and through their representation in Parliament has enormous power to determine the use of the budget. Third, as the international community, it is obliged to fully fulfil human rights and the regional budget must be used as much as possible to fulfil human rights.

The three definitions above are a unity that must always animate the understanding and implementation of the budget. Therefore, to complement the existing regional expenditure principles, the author believes that the principles that need to be considered in fulfilling human rights in the management of state finances are the Obligation of Progressive Realization in the budget.

The above principle is not new in the principles of financial management in Indonesia, so that in practice these principles have been applied in the regulation of the State and regional budgets of Indonesia. But the problem is that there is no firmness and sustainability of the above principle position, it is applied partially and not consistently. So that in terms of fulfilling human rights in the management of regional finances, the authors emphasize the inclusion of these principles in the regulation of regional financial management and the position of these principles can be used as a test tool for regional financial management.

There are four things according to the authors of the great impact of including these principles in regional financial management regulations and the position of these principles can be used as a test tool for regional financial management. The first is to prevent the government specifically the regional government from neglecting. Indonesia's challenge in the era of decentralization is the potential for massive violations of ESC rights, because of purpose and neglect.

Second, the great impact of the above for the development of human rights law in Indonesia is to strengthen justiciable position on ESC rights. Assuming that ESC Rights are positive rights, economic, social and cultural rights cannot be prosecuted in court (non-justiciable). Conversely with civil and political rights, as negative rights, it can be prosecuted in court. Besides distinguishing them in positive and negative ways, ideological differences are also made. ESC Rights are said to be ideologically charged, while civil and political rights are non-ideological, it means that ESC Rights can only be applied to a particular economic system, while civil and political rights can be applied to any economic system or any government. The article makes the government especially the regional government in a mandatory and responsible condition for fulfilling the ESC Rights and has legal consequences because of the article if it does not take compliance action.

Third, the great impact of the existence of the above mentioned for the fulfilment of human rights in Indonesia is an obligation for the government especially the local government to allocate maximum resources in the fulfilment of human rights. This maximum resource is a legal consequence of the two things above. The allocation of resources is also the basis for evaluating the government's commitment in fulfilling these rights.

Fourth, accountability, the government can be held accountable for actions in the fulfilment of human rights. The request for responsibility can be done politically by the parliament, legally by the court and administratively by the regional head's report to the people regularly along with the end of the fiscal year. And also, it can be fundamentally that the public can file criminal or civil claims to the regional government due to negligence fulfilment of the rights of ESC Rights. 


\section{E. Conclusion}

In conclusion of this article, the author needs to emphasize: first, the importance of the Principle of Progressive Realization Obligations in financial management. This is for the continuity and certainty of fulfilling human rights in the regions. The position of the obligation of progressive realization in Indonesian law is indeed not yet a positive law, but it is obligatory to implement this principle based on the state responsibility law doctrine. Secondly, there is uncertainty regarding the fulfilment of human rights in the regions, the above shows not only the very minimum budget of human rights but human rights do not get a decent budget in some regions. Third, it is necessary to change the regulation by emphasizing the Principle of Progressive Realization Obligations in the Regional Financial Management arrangements.

\section{References}

Ann Blyberg, Human Rights Budgeting and Budget Analysis, Scottish Human Rights Commission, 2008.

$\mathrm{C}$ Goedhart, in the academic text of the draft law on State Finance (translation by Ratmoko SH. Djambatan, Jakarta 1982).

Irene S Rubin, The Politics of Public Budgeting; Getting and Spending, Borrowing and Balancing,(New Jersey: hatam, 1990)

Imran, Handar Subhandi Bakhtiar and Dirga Ahmad. " Legal Standing and Authority of The Regional Representative Council in the Indonesia Constitusional System.” Amsir Law Journal 1. 2. 2020.

Office of the United Nations High Commissioner for Human Rights (OHCHR) and Internasional Budget Patnership, Realizing Human Rights Trough Goverment Budgets, New York and Geneva, 2017.

Rene Stourm, The Budget, ( D. Appleton and Company Publisher, New York 1917).

The Constitutional Court of the Republic of Indonesia, a comprehensive text on changes to the constitution of the Republic of Indonesia in 1945 Background, Process and Results Discussion in 1999-2002, REVISION EDITION, Secretariat General and Registrar of the Constitutional Court 2010.

Committee on Economic, Social and Cultural Rights, Fact Sheet Number 16 (Revised 1), World Campaign for Human Rights,

What are Minimum Core Obligations, Conceptualizing a Performative Standard for Economic, Social \& Cultural Rights to Complement Progressive Realization, 2018 Vol 2.

Regional Regulation Number 15 of 2017 concerning Regional Budget Revenue and Expenditure of Palu City in 2018

Regional Regulation 6 of 2018 concerning Regional Budget Revenue and Expenditure of Palu City in 2019 Regional Regulation Number 13 of 2019 concerning Regional Budget Revenue and Expenditure of Palu City Malang City Regulation Number 7 of 2017 concerning Regional Budget Revenue and Expenditure in 2018

Regional Regulation 6 of 2018 concerning Regional Budget Revenue and Expenditure of South Kalimantan Province in 2019

Regional Regulation Number 13 of 2019 concerning Regional Budget Revenue and Expenditure of South Kalimantan Province in 2020

Regional Regulation Number 15 of 2017 concerning Regional Budget Revenue and Expenditure of South Kalimantan Province in 2018 